World Lumen Congress 2021 | May 26-30, 2021 |

lasi, Romania

\title{
Increasing the Quality of Life of the Prison Officers and their Families by Recovering their Work Capacity
}

\author{
Carmen MATEI
}

https://doi.org/10.18662/wlc2021/41

How to cite: Matei, C. (2021). Increasing the Quality of Life of the Prison Officers and their Families by Eecovering their Work Capacity. In A. Sandu (vol. ed.), Lumen Proceedings: Vol. 17 World Lumen Congress 2021 (pp. 420-425). Iasi, Romania: LUMEN Publishing House. https://doi.org/10.18662/wlc2021/41 


\title{
Increasing the Quality of life of the Prison Officers and their Families by Recovering their Work Capacity
}

\author{
Carmen MATEI ${ }^{1}$
}

\begin{abstract}
The prison officers belong to a slightly known category, despite the transparency ensured after 1989 both by strengthening the relationship with the media institutions and by organizing the "open days" activities. They work in a closed environment between 8 and 12 hours a day, inconstant interaction with a relatively stable population the size of the administrative-territorial unit of a village type. The working schedule is on the one hand routine, on the other hand impacted by unforeseen situations, from those of major risk to those related to the management of the relationship and communication issues within the groups formed in the detention rooms.

The mission is twofold, one side consisting in actions taken to maintain the security and safety of the community and the place of detention, and the other side represent the contribution to the education / reeducation of convicts by influencing them, both directly and indirectly. The prison staff is seen as a teaching tool itself, their example being the trigger factor of the prisoners' desire to change. Taking in consideration the numerical ratio between staff and prisoners, the situations in which one can 'abdicate' from the mission are excluded, so that the efficiency of the activity is conditioned by the maintenance of a continuous state of alert.

After the working schedule, the prison officers continue their personal life, ensuring adequate emotional support for family members, participating in activities of the group of friends, etc., without projecting the accumulated stress from the workplace. But, intentionally or not, the transfer occurs, so that the effects of working in a closed environment marked by tensions and negative emotional charge are also felt by those close to them.

Through their work, the prison officers contribute to the increasing of the quality of life to the community they belong to and the quality of life in detention (ensuring community security, individual and group safety, supporting the educational/ re-educational process, ensuring somato-psycho-emotional health, etc.).Starting from this reality, through an opinion poll, we identified some of the needs to recover the work capacity, a necessary step to ensure a quality life for prison staff.
\end{abstract}

Keywords: Recovery, work capacity, quality of life, therapy, public-private partnership, education.

${ }^{1} \mathrm{PhD}$ student - School of Advanced Studies of the Romanian Academy, The Quality of Life Research Institute, Iaşi, România. e-mail: carmen.cantec@gmail.com 


\section{Work environment}

Starting with my own prison officer experience I will try to describe the work environment of this category (n. prison officer) to which majority express themselves with an inspired admiration by the exterior marks, with restraint inducted by mission and curiosity generated by activities in closed environments.

A professional officer "leaves personal issues at the door of the unit" and begins his work without being influenced by aspects of personal life. Similarly, at the end of the workday, he (n. prison officer) "leaves the professional problems at the gate of the unit" and dedicates himself to the family life. That is how I was taught by my teachers and...that is how I guided my younger colleagues. But, it's like building a wall inside your heart and mind. You have to put on your mask of dignity, hiding, to the point of denial, physical suffering or signs of fatigue, especially when you are a parent and you had awaking night next to the child who had a fever! This approach, in which the professional distance is respected and objective decisions are taken, is an inner construction in which you separate and close feelings and emotions, thoughts and impulses, offering the image of the unperturbed policeman, calm and willing to listen and act immediately to solve crisis situations and various problems.

So, what is the work environment in the penitentiary system? A prison in another prison? Both for a good social cause, for a safer community, to offer alternative perspectives to those enclosed by walls, immaturity, misfortune, etc. For those who are hiding in their hearts the child from the parental home, the matryoshka doll image is suggestive.

But, the most important aspect is the similarity between the condition of the detainee and the prison officer. They both hide things, thoughts and emotions. Both control behaviours, thoughts and emotions. Both need each other authentically, for an authentic construction, to ensure the somato-psycho-emotional balance of the detainee and facilitating his social reintegration after the execution of the custodial sentence.

The prison officer is an educator who acts through the power of personal example, but also through scientifically validated methods and techniques, he supports the detainee's self-knowledge, stimulates his will to change and motivates him to start and not abandon the long and difficult path of reconfiguring his life. You must have the tact and patience to listen to and understand the 100-200 assigned detainees, the ability and flexibility to communicate with each according to his way of being, because nothing is more dangerous than an erroneously received message, which can compromise all efforts up to a point.

From the outside it is hard to imagine that, despite the heavy punishments, every day, the prison officer hears from the same and about the same person another story, usually .... sad: the story of the indictment, the version of the detainee and the story of his life said by him or others. At the end of the program you can only be grateful for your own existence, because the good can only be known in antithesis with less well. 
In conclusion, the prison officer is the energy source to which 100-200 consumers connect to work, then the family and the support group after the workday.

Table 1. Evolution of the number of persons deprived of their libertyin custody (PDL) and the number of prison police officers during the period 2019-2020

\begin{tabular}{|c|c|c|c|}
\hline Year & 2018 & 2019 & 2020 \\
\hline $\begin{array}{l}\text { The number of } \\
\text { PDL }\end{array}$ & 20792 & 20579 & 21753 \\
\hline $\begin{array}{l}\text { The number of } \\
\text { penitentiary } \\
\text { police officers }\end{array}$ & $\begin{array}{c}\bullet \quad 8085 \\
\text { (operating sector) } \\
\bullet \quad 818 \\
\text { (social reintegration } \\
\text { sector) } \\
\bullet \quad 831 \\
\text { (medical sector) } \\
\bullet \quad 3119 \\
\text { (other sectors) }\end{array}$ & $\begin{array}{c}\bullet 7889 \\
\text { (operating sector) } \\
\bullet 773 \\
\text { (social reintegration } \\
\text { sector) } \\
\bullet 822 \\
\text { (medical sector) } \\
\bullet 3028 \\
\text { (other sectors) } \\
\end{array}$ & $\begin{array}{c}\bullet 7456 \\
\text { (operating sector) } \\
\bullet 734 \\
\text { (social reintegration } \\
\text { sector) } \\
\bullet 803 \\
\text { (medical sector) } \\
\bullet 2790 \\
\text { (other sectors) } \\
\end{array}$ \\
\hline $\begin{array}{l}\text { Total } \\
\text { penitentiary } \\
\text { police officers }\end{array}$ & 12853 & 12512 & 11783 \\
\hline
\end{tabular}

Source: the data are presented in the annual activity reports of the National Administration of Penitentiaries (2018, p. 14, 34-35; 2019, p. 12, 36-37; 2020, p. 25, 45-46)

\section{Pandemic stress}

Stress, the root of all visible or just lived diseases, has become a star over time. Fuelled by man's desire for more and better at all costs, he "grew up. "It may seem like an exaggeration, but it's not long before we respond to the good with: "Leave me, I'm stressed! I do not feel like politeness!".

And how can you not make such assessments, when, in addition to environmental pollution, interpersonal indifference, hyper technology, humanity is facing the COVID-19 coronavirus pandemic. Taken by surprise, humanity experiences the fear of the unknown being surrounded by miraculous solutions, unverified information bombardment, people like us skilled in "not wasting time for a small business". The little human being, descended from the rank of supreme creation, squats with his hands over his head and whispers tremblingly: "- What should I do ?!"

This picture argues the opportunity for additional approaches to therapy and socio-emotional education, addressed primarily to the most isolated of us, and those who work with them. There is an urgent need to learn how to live with stress, to accept it, to give it a new connotation, to reconvert its energy for the benefit of you, your family and those you care for at work. It's not easy being a prison officer. Everyone expects you to inspire courage and fearlessness. You are invested with the halo of a hero, but... you are a human being and you face the same problems as 
those who expect salvation from you. Overall, the face smiles, and the soul wonders if it does not expose some or others, at home or at work.

Table 2. Cases confirmed with SARS-CoV-2 virus between September and December2020

\begin{tabular}{|c|c|c|c|c|}
\hline Month & $\begin{array}{l}\text { September } \\
(24.09 .2020 \text {, } \\
\text { the first case } \\
\text { confirmed in } \\
\text { the Romanian } \\
\text { penitentiary } \\
\text { system) }\end{array}$ & October & November & December \\
\hline $\begin{array}{l}\text { Number of } \\
\text { persons } \\
\text { deprived of } \\
\text { their liberty }\end{array}$ & 214 & 295 & 337 & 859 \\
\hline $\begin{array}{l}\text { Number of } \\
\text { prison police }\end{array}$ & 205 & 480 & 958 & 1254 \\
\hline
\end{tabular}

Source: the data are presented in the activity report for 2020 to the National Administration of Penitentiaries (2020, p. 11)

\section{Health and health education}

"Health is a state of complete physical, mental and social well-being and not merely the absence of disease or infirmity"

(World Health Organization 1946)

Health and education are two indicators of quality of life, which are interdependent and mutually reinforcing. In closed environments where there are large populations, as are penitentiaries, it is mandatory to maintain optimal health and promote health education among prisoners. The occurrence of ill situations presents a risk for them, but also for the prison officers in whose care the detainees are. That is why, especially in the current pandemic context, it is becoming a priority to maintain and recover the work capacity of prison staff, as provided in the Article no.1 of the Law no.319 of July 14, 2006 on Safety and Health at Work.

And because "it's easier to prevent than to treat," health education is at the forefront of three goals: disease prevention, health education, and health protection.

Prevention requires good information and aims to form a lifestyle that reduces the risk of illness in children.

Health education in the detention environment is done individually or in groups, using specific standardized work tools (programs, projects, etc.) and various means (audio-video, posters, etc.), by transferring theoretical information or examples through practical applications.

Health promotion in prisons involves the involvement of all social actors (detainees, prison officers, non-governmental organizations, volunteers) in actions that lead to the creation and maintenance of a balanced social environment capable 
of ensuring for all its members a state of physical, mental and emotional well-being. Health cannot be separated from other levels of individual and collective life. Working alongside leisure has a significant impact on overall well-being. Thus, there is a need to contribute to the improvement of occupational health and psychology, by optimizing working conditions and actions to restore work capacity, expanding personal and institutional interventions to promote public-private partnerships that can ensure the diversification of different types of services.

In order to work with persons deprived of their liberty, prison staff must have optimal control over their own health, pursue continuous personal development, so that they can transfer information to guarded subjects, whose freedom of movement and access to objective information are lower.

Given the risks resulting from interactions that take place in closed environments, prison staff must show social responsibility, not only at work, but also in the community and family. Maintaining individual health is a duty and a link in the ecosystem, involving in-depth knowledge of the connections between the biotic and abiotic environment, between plants, animals and humans. The quality of social and individual life depends on the quality of knowledge, of the internalization of the moral duty to act in the sense of promoting health.

Education must not be seen as limiting, only as a way of accessing a status and social role that allows gaining income and benefits, it must become the way by which we know, respect and promote values and principles that support a complete quality life: inner well-being, cultural accumulations, common good, social wellbeing, harmonious relationships, collaborative and sustainable environments, etc. Through its purpose and objectives, health education considers the individual as part of the whole, as follows:

-creating and maintaining an inner balance that allows the preservation of individual prosocial values, as well as the discovery and development of less practiced or non-existent skills

- maintaining a state of balance and harmony within families, which is the antidote against alienation and the emergence of the phenomenon of "social loneliness" as a disease of the soul

- promoting assertive communication with detainees and co-workers. A peaceful atmosphere reduces the risk of anxiety and depression, contributes to the elimination of nervous tension (implicitly reduces the risk of aggressive and hyperaggressive behavioural manifestations)

- spending quality time with family and friends

- manifestation of concern for the environment considered "home of mankind"

- practicing non-invasive therapies to facilitate catharsis and rebalancing: melotherapy, occupational therapy, animal therapy, nature walks, etc.

\section{Conclusion}

The need for health as a common attribute of the whole food chain is a 
reminder of some basic truths, which each age has said out loud or just whispered. The duty to care for oneself, not out of selfishness but out of duty to others, is a form of externalization of a truth that has always been deeply buried in human consciousness. Although we presented a situation distinct by the specific nature of the closed environment, where any act of thought or action acquires dimensions, sometimes hyperbolic, it can be found in replicated form at different scales and in other contexts.

Preventing the occurrence of diseases and recovering health and work capacity are actions that ensure a quality life for the social environment, not just the individual. These needs are more evident in closed communities, where anxieties, as well as states of irritability or aggression, sometimes escalate. There is no need for a need to become obvious and for the action to be urgent. Any approach deserves to be replicated from the perspective of its benefits in the short, medium and long term, revaluing the function of prevention that involves avoiding high social costs.

\section{Acknowledgement}

This paper received financial support through the project entitled: DECIDE - Development through entrepreneurial education and innovative doctoral and postdoctoral research, project code POCU / 380/6/13/125031, project co-financed from the European Social Fund through the Operational Program Human Capital 2014 - 2020

\section{References}

National Administration of Penitentiaries. (2018). Raport anual de activitate [Annual activity report]. http://anp.gov.ro/wp-content/uploads/2019/03/Raport-activitate-ANP_ 2018-1.pdf

National Administration of Penitentiaries. (2019). Raport anual de activitate [Annual activity report]. http://anp.gov.ro/wp-content/uploads/2020/06/Raport-de-activitateAnul-2019.pdf

National Administration of Penitentiaries. (2020). Raport anual de activitate [Annual activity report].http://anp.gov.ro/wp-content/uploads/2021/05/Raport-de-activitate-alAdministra $\% \mathrm{C} 8 \% 9$ Biei-Na $\% \mathrm{C} 8 \% 9$ Bionale-a-Penitenciarelor-pe-anul-2020.pdf

Romanian Parliament. (2006). LEGE nr. 319 din 14 iulie 2006 a securităţii şi sănătății în muncă [Law no.319 of July 14, 2006 on Safety and Health at Work]. Monitorul Oficial nr. 646 din 26 iulie 2006 [ Official Gazette no.646 of 26 July 2006]. https://legislatie.just.ro/Public/DetaliiDocumentAfis/73772 